\title{
Inhibition of heme oxygenase activity using a microparticle formulation of zinc protoporphyrin in an acute hemolytic newborn mouse model
}

\author{
Kazumichi Fujioka ${ }^{1}$, Flora Kalish' ${ }^{1}$, Ronald J. Wong ${ }^{1}$ and David K. Stevenson ${ }^{1}$
}

\begin{abstract}
BACKGROUND: Increased bilirubin production due to hemolysis can lead to neonatal hyperbilirubinemia. Inhibition of heme oxygenase $(\mathrm{HO})$, the rate-limiting enzyme in heme catabolism, by metalloporphyrins (Mps) may be an ideal preventive strategy for neonatal hemolytic disease. Zinc protoporphyrin (ZnPP) is a naturally occurring Mp, potent, not phototoxic, with minimal HO-1 upregulation, but is not orally absorbed. Recently, we designed a lipid-based ZnPP formulation (ZnPP-Lipid), which is orally absorbed by newborn mice. Here, we evaluated the efficacy of ZnPP-Lipid in heme-loaded newborn mice, a model analogous to hemolytic infants.
\end{abstract}

METHODS: After $24 \mathrm{~h}$ of heme administration $(30 \mu \mathrm{mol} / \mathrm{kg}$ s.c.), 4-d-old mice were given $30 \mu \mathrm{mol}$ ZnPP-Lipid/kg via intragastric injections. After $3 \mathrm{~h}$, liver and brain $\mathrm{HO}$ activity were measured. $\mathrm{HO}-1$ upregulation was assessed by determinations of HO-1 protein, promoter activity, and mRNA by Western blot, in vivo bioluminescence imaging, and $R T-P C R$, respectively.

RESULTS: After heme loading, liver $\mathrm{HO}$ activity significantly increased $~ 1$.6-fold, which was inhibited in a dose-dependent manner by ZnPP-Lipid. A dose of $30 \mu \mathrm{mol} / \mathrm{kg}$ returned activity to control levels. Brain $\mathrm{HO}$ activity was not inhibited. No significant increases in liver and brain $\mathrm{HO}-1$ protein, promoter activity, and mRNA were observed.

CONCLUSION: ZnPP-Lipid is effective and thus has potential for treating neonatal hyperbilirubinemia due to hemolysis.

N eonatal jaundice commonly occurs in the first week of life, affecting $60-80 \%$ of all newborns (1). It is caused by a transient imbalance between bilirubin production and its elimination (2). Premature infants or infants with hemolytic disease or closed space bleeding are at high risk for excessive bilirubin production, which can result in bilirubin-induced neurologic dysfunction or even mortality, if left untreated (1). Currently, phototherapy is the standard treatment for neonatal hyperbilirubinemia, and exchange transfusion is reserved for extreme cases. However, both of these treatment strategies only eliminate bilirubin after it has been produced. Thus, the reduction of bilirubin production is a more logical, preventive strategy, especially when targeted at infants at risk, such as those with hemolytic disease (2).

Bilirubin is produced during the breakdown of heme derived from senescent red blood cells. This process is catalyzed by the rate-limiting enzyme, heme oxygenase $(\mathrm{HO})$, and leads to the production of equimolar amounts of carbon monoxide (CO), iron, and biliverdin, which is rapidly reduced to bilirubin (3). Thus, HO is a logical key therapeutic target for the prevention and treatment of neonatal hyperbilirubinemia $(2,4)$.

There are two primary isoforms of $\mathrm{HO}$ : the inducible $\mathrm{HO}-1$ and the constitutive HO-2 (5). The spleen is the primary organ responsible for the sequestration and degradation of senescent red blood cells and primarily expresses HO-1. However, in hemolytic conditions, the excessive heme load is degraded by the hepatic $\mathrm{HO}$ system, which expresses $\mathrm{HO}-1$ and HO-2 equally (6).

Metalloporphyrins (Mps) are synthetic derivatives of heme and also competitive inhibitors of $\mathrm{HO}(3,7,8)$. Their potency is based on their central metal and ring-side chains. Mps have been proposed for use in treating and/or preventing neonatal hyperbilirubinemia for decades $(7,9,10)$. Tin mesoporphyrin (SnMP) has been widely investigated and has even been used in human clinical trials (11-13). However, its potential side effects, such as phototoxicity (14) and an ability to significantly induce the HO-1 gene $(15,16)$, may limit its clinical use. Among other Mps, zinc protoporphyrin ( $\mathrm{ZnPP}$ ), a naturally occurring $\mathrm{Mp}$, may have more potential as it has more positive than negative characteristics (7). It has sufficient potency (6), does not cross the blood-brain barrier at therapeutic doses (17), is not photochemically active (14), minimally upregulates HO-1 (15), has a rapid onset of action and is short acting (2$12 \mathrm{~h})(18)$, and does not affect other enzymes $(7,19)$. However, $\mathrm{ZnPP}$ is not orally absorbed (20) and would require parenteral administration if used clinically. Oral administration of a compound is preferable as it results in targeted delivery to the liver due to the "first pass effect" (20).

To allow oral bioavailability and enhance gastric passage and intestinal absorption of $\mathrm{ZnPP}$, we created a lipid-based formulation of $\mathrm{ZnPP}$ (ZnPP-Lipid) and found that it has sufficient

\footnotetext{
'Department of Pediatrics, Division of Neonatal and Developmental Medicine, Stanford University School of Medicine, Stanford, California. Correspondence: Ronald J. Wong (rjwong@stanford.edu)

Received 26 March 2015; accepted 20 July 2015; advance online publication 11 November 2015. doi:10.1038/pr.2015.207
} 
potency in inhibiting liver and spleen $\mathrm{HO}$ activity in vitro and after intragastric (IG) administration, and most importantly, is neither photo- nor chemically toxic (21).

Because the most at-risk population are preterm infants, who are hemolyzing and therefore produce excessive amounts of bilirubin, we extended these studies to determine the efficacy and safety of ZnPP-Lipid using our heme-loaded newborn mouse, a model analogous to the hemolytic human infant.

\section{RESULTS}

\section{Determination of Peak Inhibitory Potency of ZnPP-Lipid}

We first determined the peak inhibitory potency of ZnPPLipid in 4-d-old mice, by measuring liver $\mathrm{HO}$ activity at 1.5 , 3,6 , and $12 \mathrm{~h}$ after IG administration of $30 \mu \mathrm{mol} / \mathrm{kg}$ body weight (BW) of ZnPP-Lipid, a dose we previously showed that significantly inhibits native liver $\mathrm{HO}$ activity in mice (21). We found that liver $\mathrm{HO}$ activity was significantly inhibited to $69 \pm 6 \%(215 \pm 19 \mathrm{pmol} / \mathrm{h} / \mathrm{mg}$ fresh weight $(\mathrm{FW}), P<0.01)$ and $73 \pm 12 \%(229 \pm 36 \mathrm{pmol} / \mathrm{h} / \mathrm{mg} \mathrm{FW}, P<0.01)$ of control levels at 3 and $6 \mathrm{~h}$, respectively, after ZnPP-Lipid administration (Figure 1). Twelve hours after treatment, $\mathrm{HO}$ activity $(319 \pm 20$ $\mathrm{pmol} \mathrm{CO} / \mathrm{h} / \mathrm{mg} \mathrm{FW}, 103 \pm 7 \%$ ) returned to control levels.

\section{Determination of Dose-Dependent Effect of ZnPP-Lipid After Heme Loading}

To confirm the feasibility of our acute hemolytic model, we first established the time course of $\mathrm{HO}$ induction in the liver of 3-d-old mice following s.c. administration of a single heme load $(30 \mu \mathrm{mol} / \mathrm{kg} \mathrm{BW})$, an oral dose we previously showed that increases liver $\mathrm{HO}$ activity ( $\sim$ twofold) of adult mice $24 \mathrm{~h}$ postadministration (22). We measured liver HO activity at 24-h intervals for up to $72 \mathrm{~h}$ after heme administration and found that $24 \mathrm{~h}$ post-administration, liver $\mathrm{HO}$ activity significantly increased 1.5-fold ( $467 \pm 45 \mathrm{pmol} \mathrm{CO} / \mathrm{h} / \mathrm{mg} \mathrm{FW}, n=12, P<$ $0.01)$ over age-matched control mice $(310 \pm 35 \mathrm{pmol} \mathrm{CO} / \mathrm{h} /$

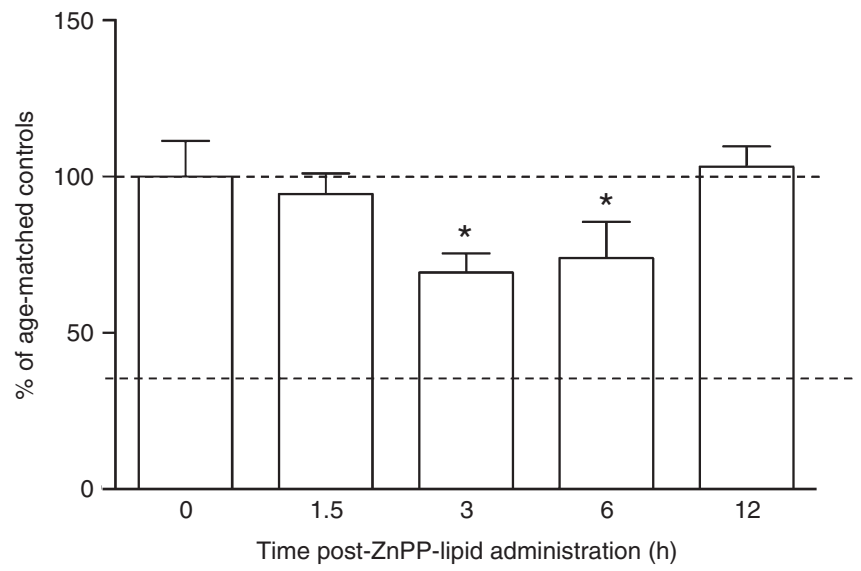

Figure 1. HO activity in the liver of mice treated with $30 \mu \mathrm{mol} \mathrm{ZnPP}$-Lipid/ $\mathrm{kg} \mathrm{BW}$ as a function of time. Liver $\mathrm{HO}$ activity was measured at $1.5 \mathrm{~h}(n=8)$, $3 \mathrm{~h}(n=5), 6 \mathrm{~h}(n=5)$, and $12 \mathrm{~h}(n=6)$ after ZnPP-Lipid IG administration to 4 -d-old mice. Data are expressed as \% liver HO activity (mean \pm SD) of control $(t=0 \mathrm{~h})$ pups $(n=20) .{ }^{*} P<0.05$ compared with controls $(t=0 \mathrm{~h})$. BW, body weight; HO, heme oxygenase; IG, intragastric; ZnPP, zinc protoporphyrin. mg FW, $n=20)$. Liver $\mathrm{HO}$ activity returned to baseline levels by $48 \mathrm{~h}(309 \pm 36, n=13$ vs. age-matched controls: $312 \pm 52$ $\mathrm{pmol} \mathrm{CO} / \mathrm{h} / \mathrm{mg} \mathrm{FW}, n=11)$ and remained there for at least $72 \mathrm{~h}(297 \pm 64, n=10$ vs. age-matched controls: $289 \pm 39 \mathrm{pmol}$ $\mathrm{CO} / \mathrm{h} / \mathrm{mg} \mathrm{FW}, n=15$ ).

Because peak induction of liver $\mathrm{HO}$ activity by heme occurred $24 \mathrm{~h}$ post-administration, we treated mice with $\mathrm{ZnPP}$-Lipid at this time (or day 4 of life). Since the peak inhibitory potency of $\mathrm{ZnPP}$-Lipid was observed $3 \mathrm{~h}$ after administration, we measured liver $\mathrm{HO}$ activity at $27 \mathrm{~h}(505 \pm 102 \mathrm{pmol} \mathrm{CO} / \mathrm{h} / \mathrm{mg} \mathrm{FW}$, $n=28), 30 \mathrm{~h}(369 \pm 41 \mathrm{pmol} \mathrm{CO} / \mathrm{h} / \mathrm{mg} \mathrm{FW}, n=7)$, and $36 \mathrm{~h}$ (406 $\pm 42 \mathrm{pmol} \mathrm{CO} / \mathrm{h} / \mathrm{mg} \mathrm{FW}, n=5)$ post-heme administration, which corresponded to 3,6 , and $12 \mathrm{~h}$ post-ZnPP-Lipid time points. Because there was no significant differences in $\mathrm{HO}$ activity 24 and $27 \mathrm{~h}$ post-heme treatment, these data were combined for the "Heme" group (494 $\pm 90 \mathrm{pmol} \mathrm{CO} / \mathrm{h} / \mathrm{mg} \mathrm{FW}$, $n=40$; Figure 2). To determine if there was a dose-dependent effect of ZnPP-Lipid using this acute hemolytic model, $\mathrm{HO}$ activity was measured $3 \mathrm{~h}$ after ZnPP-Lipid IG administration at various doses (1.9-60 $\mu \mathrm{mol} / \mathrm{kg} \mathrm{BW)} \mathrm{(Figure} \mathrm{2).} \mathrm{Three} \mathrm{hours}$ after ZnPP-Lipid treatment, liver $\mathrm{HO}$ activity was significantly inhibited in a dose-dependent manner, decreasing from $159 \%$ (heme only) to $96 \%$ at $60 \mu \mathrm{mol} \mathrm{ZnPP}-\mathrm{Lipid} / \mathrm{kg} \mathrm{BW}$. We found that a dose of $30 \mu \mathrm{mol} / \mathrm{kg}$ BW completely abolished the hemeinduced increase in liver $\mathrm{HO}$ activity to control levels $(309 \pm 67$ $\mathrm{pmol} \mathrm{CO} / \mathrm{h} / \mathrm{mg} \mathrm{FW}, 100 \pm 22 \%, n=24)$.

Next, we examined whether this minimal effective dose had inhibitory effects on HO activity of the brain, a nontarget organ. In the native mouse, $3 \mathrm{~h}$ after $\mathrm{ZnPP}$-Lipid administration, no significant change in the $\mathrm{HO}$ activity at a dose of 30 or $60 \mu \mathrm{mol} / \mathrm{kg} \mathrm{BW} \mathrm{(Veh} \mathrm{+} \mathrm{ZL30:} 73 \pm 11$, $101 \pm 15 \%, n=4$ and Veh + ZL60: $72 \pm 11 \mathrm{pmol} \mathrm{CO} / \mathrm{h} / \mathrm{mg}$ FW, $99 \pm 15 \%, n=4$, respectively) was found compared to

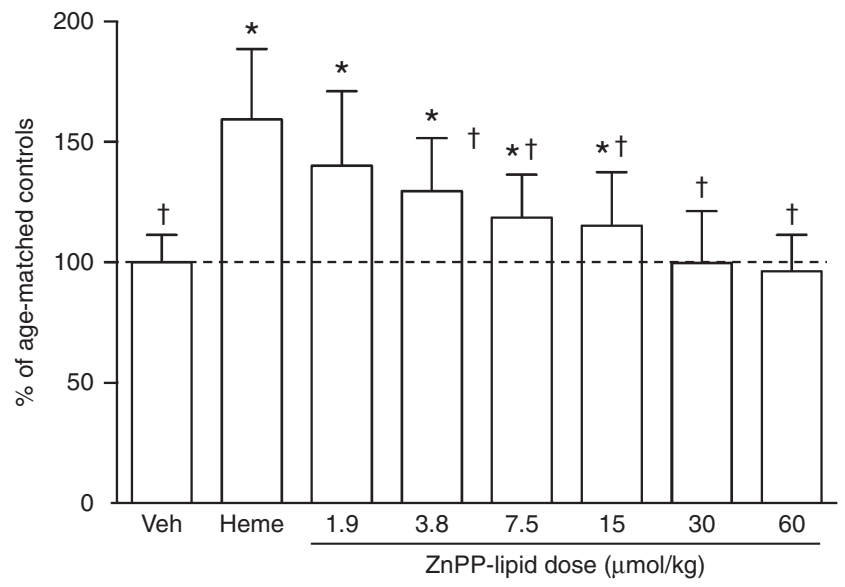

Figure 2. HO activity in the liver of heme-loaded mice treated with $30 \mu \mathrm{mol} Z \mathrm{nPP}$-Lipid/kg BW as a function of dose. Liver $\mathrm{HO}$ activity was measured $3 \mathrm{~h}$ after IG administration of $1.9(n=11), 3.8(n=11), 7.5$ ( $n=18), 15$ ( $n=19), 30(n=24)$, and $60(n=11) \mu \mathrm{mol}$ ZnPP-Lipid/kg BW to heme-loaded 4-d-old mice. Data are expressed as \% liver $\mathrm{HO}$ activity (mean \pm SD) of age-matched vehicle-treated controls (Veh). ${ }^{*} P<0.05$ compared with vehicle-treated controls (Veh); ${ }^{\dagger} P<0.05$ compared with heme-only-treated pups (Heme, positive control). BW, body weight; $\mathrm{HO}$, heme oxygenase; IG, intragastric; ZnPP, zinc protoporphyrin. 
age-matched vehicle-treated controls $(72 \pm 10 \mathrm{pmol} \mathrm{CO} / \mathrm{h} /$ mg FW, $100 \pm 14 \%, n=5$ ).

In heme-loaded pups, brain $\mathrm{HO}$ activity did not significantly increase $(68 \pm 6 \mathrm{pmol} \mathrm{CO} / \mathrm{h} / \mathrm{mg} \mathrm{FW}, 94 \pm 8 \%, n=8)$ compared to vehicle-treated controls $(72 \pm 10 \mathrm{pmol} \mathrm{CO} / \mathrm{h} / \mathrm{mg} \mathrm{FW}, 100 \pm 14 \%$, $n=5)$. In addition, a dose of 30 or $60 \mu \mathrm{mol} / \mathrm{kg} \mathrm{BW}(68 \pm 7 \mathrm{pmol}$ $\mathrm{CO} / \mathrm{h} / \mathrm{mg} \mathrm{FW}, 95 \pm 10 \%, n=6$ and $73 \pm 7 \mathrm{pmol} \mathrm{CO} / \mathrm{h} / \mathrm{mg} \mathrm{FW}$, $101 \pm 10 \%, n=4$, respectively) did not affect brain $\mathrm{HO}$ activity.

\section{Determination of HO-1 Upregulation of ZnPP-Lipid}

Next, to evaluate whether the administration of ZnPP-Lipid upregulated $\mathrm{HO}-1$, we measured $\mathrm{HO}-1$ protein, $\mathrm{HO}-1$ promoter activity, HO-1 mRNA, by Western blot analysis, in vivo bioluminescence imaging (BLI), and RT-PCR, respectively.

HO-1 protein levels. First, we determined HO-1 protein upregulation in liver and brain $24 \mathrm{~h}$ after ZnPP-Lipid administration (Figure 3). Twenty-four hours following a single heme load (Heme), liver HO-1 protein levels increased 1.9-fold over vehicle-treated controls $($ Veh + Veh $)(P<0.01)$, as expected. Forty-eight hours after heme administration, HO-1 protein levels returned to control (Heme + Veh vs. Veh + Veh) levels (Figure 3a). After treatment with $30 \mu \mathrm{mol} \mathrm{ZnPP-Lipid/kg}$ $\mathrm{BW}$, we found a 1.3-fold increase in liver HO-1 protein levels, which was not statistically significant (Heme + ZL30) compared with vehicle-treated controls (Veh + Veh). In contrast, brain protein levels did not increase after heme loading (Heme + Veh) or ZnPP-Lipid (Heme + ZL30) treatment (Figure 3c). Figure $3 \mathbf{b}, \mathbf{d}$ show that both liver and brain $\mathrm{HO}-1$ protein levels returned to baseline levels $72 \mathrm{~h}$ post-heme $(\mathrm{Heme}+\mathrm{Veh})$ and $48 \mathrm{~h}$ post-ZnPP-Lipid (Heme + ZL30) treatments.

HO-1 promoter activity. Next, to determine effect of ZnPPLipid on HO-1 promoter activity, we adapted the abovementioned experimental protocol to $\mathrm{HO}-1$-luc-mice, whose transgene consists of the full-length $(15 \mathrm{~kb}) \mathrm{HO}-1$ promoter driving expression of the reporter gene, luciferase (luc). In vivo $\mathrm{HO}-1$ promoter activity was monitored by BLI at 0, 3, 6, and $24 \mathrm{~h}$ after heme and ZnPP-Lipid administration and shown in Figure 4 for the liver (Figure $4 a, b$ ) and brain (Figure 4c,d). After heme administration, HO-1 transcription in the abdominal region (liver) significantly increased and peaked to $2.5 \pm 2.4$-fold over baseline levels at $6 \mathrm{~h}(P<0.01)$ and decreased to $1.8 \pm 1.3$-fold $(P<0.01)$ by $24 \mathrm{~h}$ (Figure $4 \mathrm{a}$ ). After ZnPP-Lipid administration to heme-loaded pups, HO-1 transcription rates in the abdominal region did not increase from baseline levels $3 \mathrm{~h}(0.44 \pm 0.2$-fold $), 6 \mathrm{~h}$ ( $0.81 \pm 0.6$-fold $)$, and $24 \mathrm{~h}$ (1.2 \pm 0.9 -fold) after treatment (Figure $4 \mathrm{~b})$.
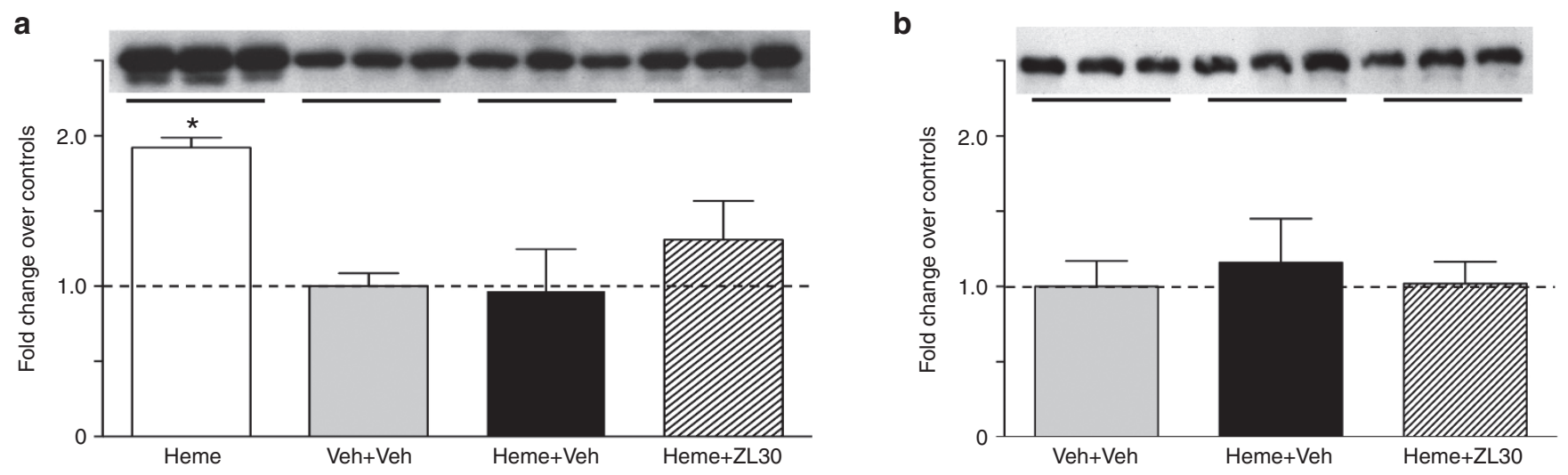

C

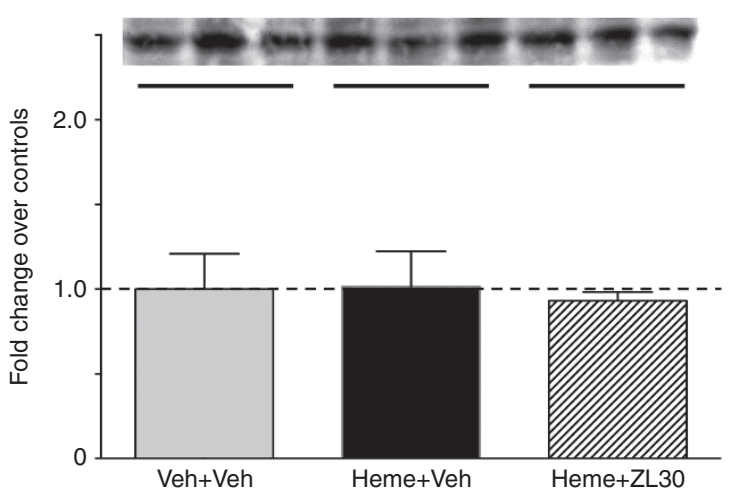

d

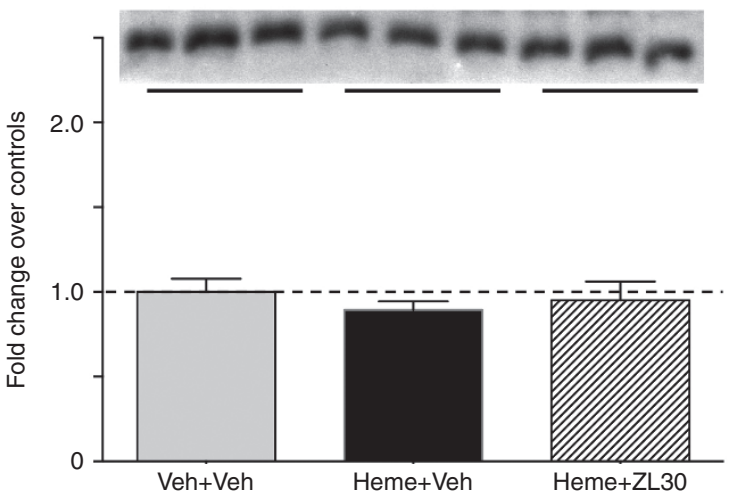

Figure 3. HO-1 protein levels after ZnPP-Lipid administration of $30 \mu \mathrm{mol}$ ZnPP-Lipid/kg BW to heme-loaded mouse pups. HO-1 protein levels were measured 24 and $48 \mathrm{~h}$ after ZnPP-Lipid administration (Heme + ZL30) in the liver ( $\mathbf{a}$ and $\mathbf{b}$, respectively) and brain (c and d, respectively). Data are expressed as fold change (mean \pm SD) from controls. ${ }^{*} P<0.05$ compared with vehicle-treated controls (Veh + Veh). $n=3$ mice for each treatment group. BW, body weight; HO, heme oxygenase; ZnPP, zinc protoporphyrin. 
a
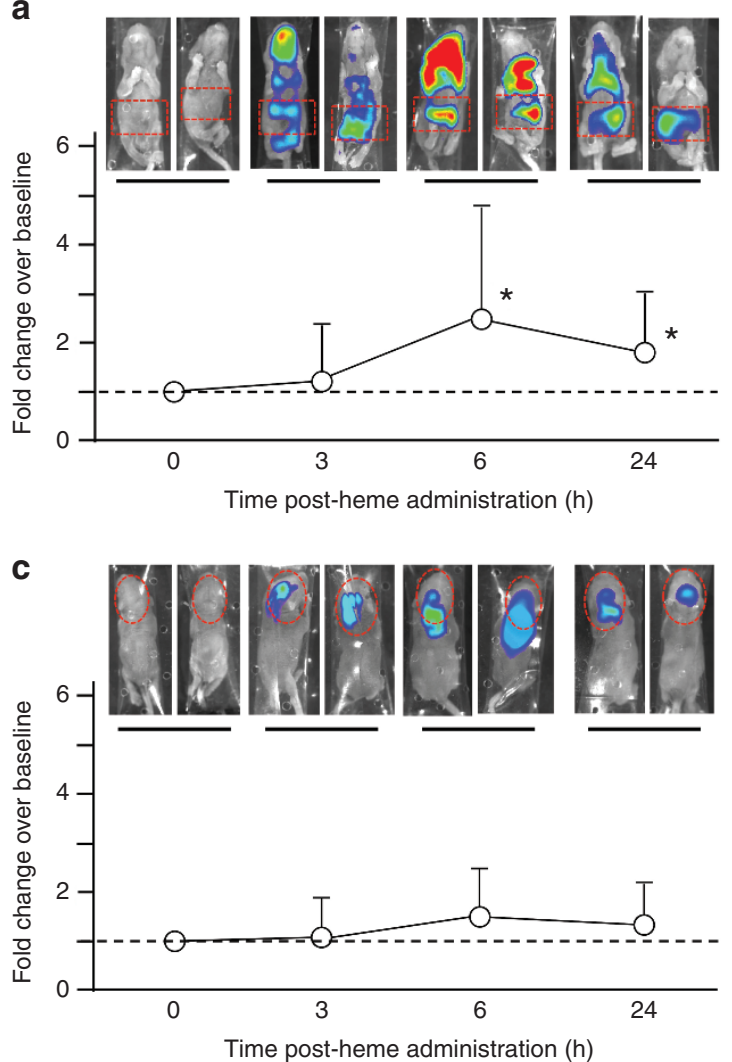

b

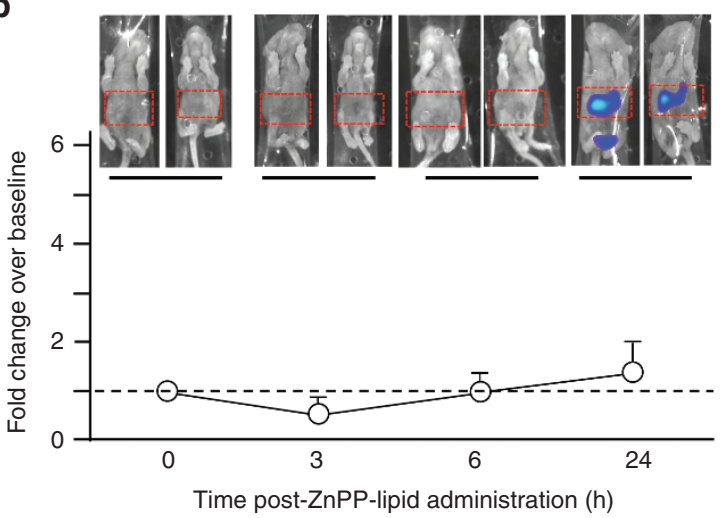

d

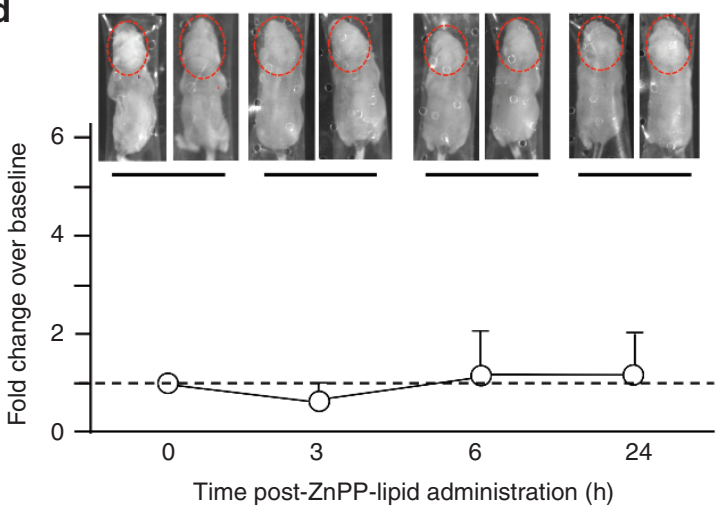

Figure 4. In vivo HO-1 promoter activity in mice treated with $30 \mu \mathrm{mol}$ heme or ZnPP-Lipid/kg BW as a function of time in the liver (a and $\mathbf{b}$, respectively) and brain (c and d, respectively). In vivo HO-1 promoter activity was assessed by BLI in the abdominal (representing the liver) or head (representing the brain) regions of 3- or 4-d-old mice at $0,3,6$, and $24 \mathrm{~h}$ after treatment. Total number of photons emitted/sec (or flux) was quantitated at each time point and then expressed as fold change (mean \pm SD) from baseline levels. Representative images per each mouse are shown using the same scale of total flux (photons emitted per sec) for each treatment group. ${ }^{*} P<0.05$ compared with baseline levels $(t=0 \mathrm{~h}) . n \geq 12$ for each treatment group and time point. BLI, bioluminescence imaging; BW, body weight; $\mathrm{HO}$, heme oxygenase; ZnPP, zinc protoporphyrin.

For the brain, there was no significant increase in HO-1 transcription after heme (Figure 4c) or ZnPP-Lipid (Figure 4d) administration at any time point.

HO-1 mRNA levels. To corroborate our liver HO-1 protein and $\mathrm{HO}-1$ transcriptional findings, we compared HO-1 mRNA levels between vehicle-treated controls (Veh + Veh), hemeloaded mice (Heme + Veh), ZnPP-Lipid-treated heme-loaded mice (Heme + ZL30), and heme-treated positive controls at $6 \mathrm{~h}$ post-treatment. We found that HO-1 mRNA levels significantly increased $2.3 \pm 1.0$-fold at $6 \mathrm{~h}$ after heme administration $(P=$ $0.01)$, however, there were no significant difference between Veh + Veh, Heme + Veh, and Heme + ZL30 pups (Figure 5).

\section{DISCUSSION}

Despite established standard treatment strategies (i.e., phototherapy and exchange transfusion) for neonatal hyperbilirubinemia, kernicterus, the chronic and permanent clinical sequelae of bilirubin toxicity, is still occurring in North America, and the incidence is much higher in developing countries (1). Adverse complications of these conventional therapies are still being reported, such as increased mortality of extremely premature infants and DNA damage under phototherapy $(23,24)$ and increased mortality and hematological

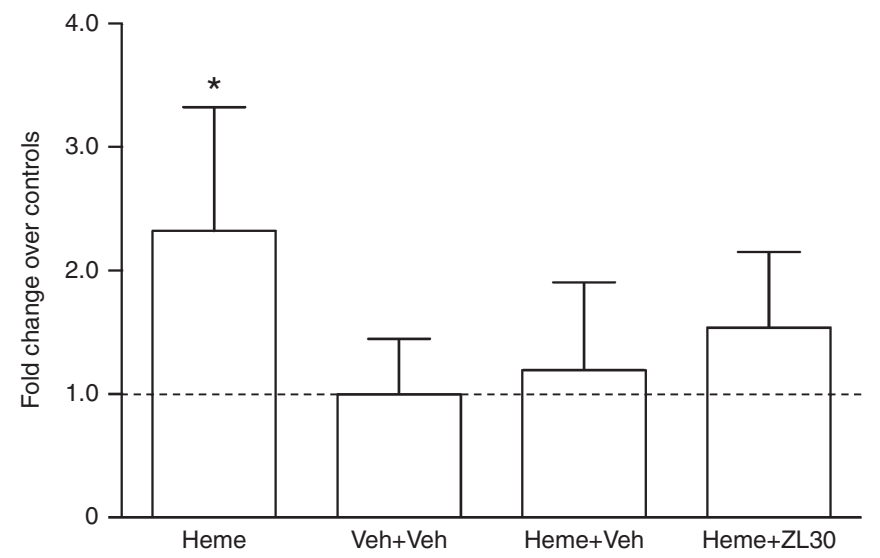

Figure 5. HO-1 mRNA levels in the liver after ZnPP-Lipid administration of $30 \mu \mathrm{mol}$ ZnPP-Lipid/kg BW to heme-loaded pups. Liver HO-1 mRNA levels were measured $6 \mathrm{~h}$ after administration of ZnPP-Lipid (Heme $+\mathrm{ZL30}$ ) and normalized to $\beta$-actin mRNA levels in the same tissues. ${ }^{*} P<0.05 \mathrm{com}$ pared with controls (Veh + Veh). $n=6$ for each treatment group. BW, body weight; $\mathrm{HO}$, heme oxygenase; $\mathrm{ZnPP}$, zinc protoporphyrin.

or cardiorespiratory disturbances after exchange transfusions (25). In addition, these treatments are not readily available in resource-limited settings. Thus, the development of alternative convenient therapeutic strategies remains an urgent necessity. 
Among the Mps studied to date, only tin protoporphyrin (SnPP) and SnMP have been tested in human clinical trials. They appeared to have significant effects in lowering plasma bilirubin levels, however, were not shown to be superior to phototherapy in treating neonatal jaundice. In addition, treated infants showed a photosensitivity when phototherapy was applied (10). In addition, we have found that zinc deuteroporphyrin bis-glycol (ZnBG) and chromium mesoporphyrin (CrMP) have photo- and chemical toxicity, respectively, despite both being highly potent (26). And, except in two healthy adult studies showing no oral absorbance of SnPP (27) and SnMP (28), all the Mps tested in earlier trials have been administered parenterally (i.v. or i.m.) (10). The oral route is the most convenient and comfortable means of administration for pharmaceutical products (29), and for Mps, the "first pass effect" allows for a targeted inhibition of $\mathrm{HO}$ activity in the liver, the main organ that degrades excessive heme loads in hemolytic conditions.

$\mathrm{ZnPP}$ has been studied for potential use for the treatment of neonatal hyperbilirubinemia for decades $(7,17,20)$. In rhesus neonates, $\mathrm{ZnPP}$ at a dose of $40 \mu \mathrm{mol} / \mathrm{kg}$ BW given s.c. reduced total bilirubin levels within $24 \mathrm{~h}$ and lasted $12 \mathrm{~d}$ (17). In rats, $\mathrm{ZnPP}(40 \mu \mathrm{mol} / \mathrm{kg}$ BW i.p.) inhibited hepatic HO activity rapidly and with a relatively short duration of action (1-4 d) in adults (18) and neonates (30). In addition, we have previously shown ZnPP effectively inhibits HO-1 with a relative sparing of the housekeeping $\mathrm{HO}-2$, a predominant form in most organs under homeostatic conditions (6).

Because $\mathrm{ZnPP}$ has been shown not to be orally absorbed, we used spray-drying techniques to incorporate $\mathrm{ZnPP}$ into biodegradable endogenous phospholipids, 1,2-dipalmitoylsn-glycero-3-phosphocholine (DPPC) and 1,2-distearoyl-snglycero-3-phosphocholine (DSPC), and created ZnPP-Lipid to improve stability and enhance intestinal absorption. We chose to use these lipid microparticles because they are already approved by the FDA for use in premature infants as components of synthetic surfactants (21).

We have developed several animal models to mimic hemolysis in the human infant in order to investigate the therapeutic potency of Mps for neonatal hyperbilirubinemia due to hemolytic diseases. We have shown that the administration of heme results in an increase in in vivo bilirubin production and therefore can be used as a model of hemolysis in primates, rats, adult mice, and 1-wk-old newborn mice (22,31-33). In this study, we adapted this procedure to 3-d-old mice, which are roughly equivalent in age to preterm human infants (34) and a useful model of hemolytic disease in preterm neonates.

In this study, we first demonstrated that ZnPP-Lipid has a rapid onset $(\leq 3 \mathrm{~h})$ and short duration of action $(\leq 12 \mathrm{~h})$ for inhibiting liver $\mathrm{HO}$ activity, with peak potency $3 \mathrm{~h}$ postadministration. Subsequently, by applying our acute hemolytic newborn mouse model, we observed that: (i) inhibition of liver $\mathrm{HO}$ activity by ZnPP-Lipid was dose dependent, with a dose of $30 \mu \mathrm{mol} / \mathrm{kg}$ BW completely abolishing the heme-induced increase in $\mathrm{HO}$ activity and (ii) at doses of 30 and $60 \mu \mathrm{mol} /$ kg BW, ZnPP-Lipid did not affect brain HO activity and HO-1 protein levels. These doses are comparable to the dose of $\mathrm{ZnPP}$ $(40 \mu \mathrm{mol} / \mathrm{kg} \mathrm{BW})$ used in our previous study that completely negated the increase in bilirubin production in heme-loaded rhesus neonates, when administered i.v. (35).

With regards to undesirable effects of Mps, we did not observe significant $\mathrm{HO}-1$ upregulation or increases in $\mathrm{HO}-1$ promoter activity $(3,6$, and $24 \mathrm{~h})$, mRNA $(6 \mathrm{~h})$, or protein levels (24 and $48 \mathrm{~h}$ ) after ZnPP-Lipid treatment in livers and brains. In addition, since we found that HO-1 protein levels already returned to baseline $48 \mathrm{~h}$ post-heme loading (Figure 3a,c), HO-1 protein levels in the Heme + ZL30 group reflected the effects of ZnPP-Lipid alone, which did not lead to an upregulation of liver or brain HO-1 protein and equivalent to age-matched control levels. These findings are consistent with our previous observations using adult mice, where we found no significant changes in the liver $\mathrm{HO}-1$ protein 24 and $48 \mathrm{~h}$ after oral administration of $30 \mu \mathrm{mol} / \mathrm{kg}$ BW of ZnPP (36). In addition, ZnPP-Lipid had no inhibitory effect on brain, a nontarget organ, consistent with it not crossing the blood/brain barrier at those doses. In regards to photosensitivity, we have previously shown that even at a dose of $60 \mu \mathrm{mol} / \mathrm{kg}$ BW, ZnPP-Lipid (and the lipid vehicle alone) was not phototoxic to newborn mice exposed to fluorescent light (21). Furthermore, Maines have shown that ZnPP does not alter the other enzymatic activities, such as $\delta$-aminolevulinate synthetase and cytochrome $P-450$, in the rat spleen and liver (7). In addition, we previously have shown that an aqueous formulation of ZnPP does not inhibit enzyme activity of nitric oxide synthase or soluble guanylyl cyclase in vitro (19). Because our ZnPP-Lipid formulation consisted of $90 \%$ of phospholipids (45\% DSPC and 45\% DPPC), the concentration of DPPC was only $99 \mathrm{mg} / \mathrm{kg}$, which is $\sim 56 \%$ of that present in FDA-approved commercially available synthetic surfactants of $175 \mathrm{mg} / \mathrm{kg}$ and deemed safe (37). In addition, DPPC and DSPC have been shown to not affect nitric oxide synthase activity in mouse endothelial cells at concentrations 10-fold higher those used in our study concentration (38).

In addition to these safe properties of ZnPP-Lipid, it also has a short duration of action in the heme-loaded mouse pups, similar to that found in rats (18). As neonatal hyperbilirubinemia is a physiologic and transitional condition, this pharmacological property of ZnPP-Lipid makes it ideal for clinical use $(9,30)$. In addition, our proposed oral delivery of compound would be helpful for those children living in developing countries, where access to conventional therapy is limited or even unavailable.

The limitations of this study are that we could not assess the $\mathrm{HO}$ inhibitory effect of ZnPP-Lipid in the spleen due to the small size and weight of the spleens of 4-d-old mice. However, as we (33) and Maines (5) have reported previously, spleen HO-1 is already maximally upregulated in normal conditions since it is the primary organ for red blood cell turnover. Although we also did not show a direct bilirubin lowering ability of ZnPPLipid due to the small blood volumes of the newborn pups, we did establish that the $30 \mu \mathrm{mol} / \mathrm{kg}$ of ZnPP-Lipid can effectively inhibit increases in total body $\mathrm{CO}$ excretion rates or $\mathrm{VeCO}$ 
(an index of in vivo bilirubin production rates (39) in hemeloaded mouse pups (see Supplementary Figure S1 online). In addition, we (35) and others (17) have previously shown that after ZnPP treatment, bilirubin levels decreased as well as liver and spleen $\mathrm{HO}$ inhibition in nonhuman primates, which supports our hypothesis. The distribution of ZnPP-Lipid in the body was not determined, but we have previously reported that after i.p. administration, ZnPP primarily distributes to the liver and corresponds to a significant liver $\mathrm{HO}$ inhibitory effect in neonatal rats (30). This result suggests that the amount of deposition corresponds to the level of tissue $\mathrm{HO}$ inhibition.

In conclusion, ZnPP-Lipid is effective and an attractive compound for oral use in the treatment of neonatal hyperbilirubinemia caused by hemolytic diseases. Before clinical applications, we need to investigate the efficacy and safety of this compound in nonhuman primates.

\section{METHODS}

\section{Animals}

For these studies, 3-d-old newborn FVB mice or HO-1-luc mice were used. Stanford University's Institutional Animal Care and Use Committee approved animal use for this study. Pups were kept with their mothers throughout the course of the study.

\section{Reagents}

A stock solution of $4 \mathrm{mmol} / \mathrm{l} \mathrm{ZnPP-Lipid} \mathrm{(containing} \mathrm{DPPC} \mathrm{and}$ DSPC) was prepared as previously described (21). Briefly, $6.26 \mathrm{mg}$ of $\mathrm{ZnPP}$-Lipid was dissolved in $250 \mu \mathrm{l} \mathrm{NaCl}$ and vigorously vortexed just prior to administration.

A $4.5 \mathrm{mmol} / \mathrm{l}$ solution of reduced nicotinamide adenine dinucleotide phosphate (NADPH; Calbiochem, La Jolla, CA) was prepared by dissolving $3.82 \mathrm{mg}$ of $\mathrm{Na}_{4} \mathrm{NADPH}$ in $1.0 \mathrm{ml}$ of $0.1 \mathrm{~mol} / 1 \mathrm{KPO}_{4}$.

A stock solution of $1.5 \mathrm{mmol} / \mathrm{l}$ methemalbumin used for the $\mathrm{HO}$ activity assay and $4.0 \mathrm{mmol} / \mathrm{l}$ used for s.c. injection were prepared with hemin and bovine serum albumin (Sigma-Aldrich, St Louis, $\mathrm{MO}$ ) as previously described (36). For the HO activity assay, a working solution of $150 \mu \mathrm{mol} / \mathrm{l}$ methemalbumin was prepared daily by diluting the stock solution with $0.1 \mathrm{~mol} / 1 \mathrm{KPO}_{4}$.

\section{In Vivo BLI}

In vivo $\mathrm{HO}-1$ transcription was measured by BLI using the In Vivo Imaging System (IVIS; Caliper Life Sciences, Alameda, CA) as described previously (36). Ten minutes before imaging, $150 \mathrm{mg}$ luciferin/kg BW was administered i.p. to 3-d-old HO-1-luc mice. Mice were wrapped in clear perforated vinyl film to immobilize each mouse without the need for anesthesia. Mice were then placed in the IVIS and the photons emitted from the tissues were quantitated using LivingImage software (Caliper Life Sciences), calculated as total flux (photons emitted/sec), and expressed as fold change from baseline levels. Measurements were taken at the ventral and dorsal aspects of each mouse, representing the liver and brain.

\section{Tissue Preparation}

After mice were sacrificed, livers and brains were harvested and rinsed with ice-cold $0.1 \mathrm{~mol} / 1 \mathrm{KPO}_{4}$. One hundred milligrams of each tissue were diluted $10 \times$ with $0.1 \mathrm{~mol} / 1 \mathrm{KPO}$. Tissues were sonicated at $50 \%$ power with a Microson Ultrasonic Cell Disruptor (Misonix, Farmingdale, NY).

\section{HO Activity}

Because equimolar quantities of $\mathrm{CO}$ and bilirubin are produced during heme degradation, the production of $\mathrm{CO}$ in the presence of heme and NADPH in tissue sonicates can be used as an index of HO activity (40). Tissue sonicates ( $20 \mu \mathrm{l}$ : representing $2 \mathrm{mg}$ of liver and brain) were incubated with equal $(20 \mu \mathrm{l})$ volumes of NADPH $(4.5 \mathrm{mmol} / \mathrm{l})$ and methemalbumin $(150 \mu \mathrm{mol} / \mathrm{l}$ heme $/ 15 \mu \mathrm{mol} / \mathrm{l}$ bovine serum albumin $)$ for $15 \mathrm{~min}$ at $37^{\circ} \mathrm{C}$ in $2-\mathrm{ml} \mathrm{CO}$-purged septum-sealed vials. Reactions were terminated with the addition of $5-\mu l 15 \%$ sulfosalicylic acid. The amount of $\mathrm{CO}$ in the vial headspace was determined by gas chromatography with a Reduction Gas Analyzer (RGA-2; Peak Laboratories LLC, Mountain View, CA). HO activity was calculated as pmol CO/h/ mg FW and expressed as \% $\mathrm{HO}$ activity of age-matched control levels.

\section{Western Blots}

Following standard laboratory procedures $(33,36), 80$ and $200 \mu \mathrm{g}$ of tissue sonicates of liver and brain were electrophoresed on a $12 \%$ polyacrylamide gel and then transferred to polyvinylidene fluoride membrane (Bio-Rad, Hercules, CA) and then incubated with the primary (HO-1) and secondary antibodies. Antigen-antibody complexes were visualized with ECL Western Blotting Detection Reagents. Band intensities will be determined by densitometry and then expressed as fold change from vehicle-treated controls.

\section{RT-PCR}

Approximately 5- $\times 5-\times 1-\mathrm{mm}$ pieces of liver and brain were taken immediately after sacrifice, placed in liquid nitrogen, and stored at $-80{ }^{\circ} \mathrm{C}$ until use. Total RNA was extracted and HO- 1 mRNA was measured by RT-PCR according to standard laboratory procedures using the RNAeasy Mini Kit (Qiagen, Valencia, CA) and a Mx-3005 Quantitative PCR System (Stratagene, Cedar Creek, TX) (33,36). Copy number/ $\mu$ g total RNA per sample was calculated from a standard curve. All results were normalized to $\beta$-actin mRNA levels in the same tissues and expressed as fold change (mean $\pm \mathrm{SD}$ ) from baseline levels.

\section{Heme-Loaded Study Design}

At $t=0 \mathrm{~h}$ (or day 3 of life), vehicle or $30 \mu \mathrm{mol}$ heme $/ \mathrm{kg}$ BW were administered via s.c. At $t=24 \mathrm{~h}$ (or day 4 of life), vehicle or $30 \mu \mathrm{mol}$ $\mathrm{ZnPP}$-Lipid/kg BW was administered via IG. At $t=27 \mathrm{~h}$, animals were sacrificed, and liver and brain tissues were harvested for in vitro assays of $\mathrm{HO}$ activity. At $t=30 \mathrm{~h}$ (or $6 \mathrm{~h}$ after ZnPP-Lipid treatment), a separate set of animals were treated with Veh + Veh, Heme + Veh, or Heme + ZL30 was used to assess HO-1 mRNA levels in the liver. At $t=48 \mathrm{~h}$ (or $24 \mathrm{~h}$ after ZnPP-Lipid treatment), another set of animals treated with Veh + Veh, Heme + Veh, or Heme + ZL30 was sacrificed, then liver and brain tissues were harvested for HO-1 protein levels.

\section{BLI Study Design}

After establishment of baseline levels of HO-1 transcriptional activity by BLI, $30 \mu \mathrm{mol}$ heme $/ \mathrm{kg} \mathrm{BW}$ was administered via s.c. at $t=0 \mathrm{~h}$. Subsequently, BLI was monitored at $t=3,6$, and $24 \mathrm{~h}$, then compared with baseline levels $(t=0 \mathrm{~h})$. At $t=24 \mathrm{~h}, 30 \mu \mathrm{mol} \mathrm{ZnPP-Lipid} / \mathrm{kg} \mathrm{BW}$ was administered IG. Subsequently, BLI was monitored at $t=27,30$, and $48 \mathrm{~h}$, then compared with baseline levels $(t=24 \mathrm{~h})$.

\section{Statistical Analyses}

Statistical analyses were performed between vehicle-treated and heme- and/or ZnPP-Lipid-treated pups using unpaired Student's two-tailed $t$-test. Differences were deemed significant when $P<0.05$.

\section{SUPPLEMENTARY MATERIAL}

Supplementary material is linked to the online version of the paper at http://www.nature.com/pr

\section{ACKNOWLEDGMENTS}

We thank Jayakumar Rajadas, Cecilia Espadas, and Mohammed Inayathullah at BioADD (Biomaterials and Advanced Drug Delivery Laboratory, Stanford, CA) for designing and providing the formulations. We also thank Hui Zhao for her invaluable advice on our experimental design and Hendrik J.Vreman for his critical review on our manuscript.

\section{STATEMENT OF FINANCIAL SUPPORT}

This work was supported by the Christopher Hess Research Fund (Palo Alto, CA), the H.M. Lui Research Fund (Hong Kong, China), the Mary L. Johnson Research Fund (Palo Alto, CA), the Child Health Research Institute (Stanford, CA), the SPARK Program at Stanford (Stanford, CA), the Japan Foundation for Pediatric Research (Tokyo, Japan), and the Uehara Memorial Foundation (Tokyo, Japan).

Disclosure: There is no conflict of interest to disclose. 


\section{REFERENCES}

1. American Academy of Pediatrics. Management of hyperbilirubinemia in the newborn infant 35 or more weeks of gestation. Pediatrics 2004;114: 297-316.

2. Stevenson DK, Rodgers PA, Vreman HJ. The use of metalloporphyrins for the chemoprevention of neonatal jaundice. Am J Dis Child 1989;143: 353-6.

3. Tenhunen R, Marver HS, Schmid R. The enzymatic conversion of heme to bilirubin by microsomal heme oxygenase. Proc Natl Acad Sci USA 1968;61:748-55.

4. Drummond GS, Kappas A. Chemoprevention of neonatal jaundice: potency of tin-protoporphyrin in an animal model. Science 1982;217:1250-2.

5. Maines MD. The heme oxygenase system: update 2005. Antioxid Redox Signal 2005;7:1761-6.

6. Wong RJ, Vreman HJ, Schulz S, Kalish FS, Pierce NW, Stevenson DK. In vitro inhibition of heme oxygenase isoenzymes by metalloporphyrins. J Perinatol 2011;31:Suppl 1:S35-41.

7. Maines MD. Zinc. protoporphyrin is a selective inhibitor of heme oxygenase activity in the neonatal rat. Biochim Biophys Acta 1981;673:339-50.

8. Drummond GS, Kappas A. Prevention of neonatal hyperbilirubinemia by tin protoporphyrin IX, a potent competitive inhibitor of heme oxidation. Proc Natl Acad Sci USA 1981;78:6466-70.

9. Vreman HJ, Wong RJ, Stevenson DK. Alternative metalloporphyrins for the treatment of neonatal jaundice. J Perinatol 2001;21:Suppl 1:S108-13; discussion S125-7.

10. Schulz S, Wong RJ, Vreman HJ, Stevenson DK. Metalloporphyrins - an update. Front Pharmacol 2012;3:68.

11. Kappas A, Drummond GS, Valaes T. A single dose of Sn-mesoporphyrin prevents development of severe hyperbilirubinemia in glucose-6-phosphate dehydrogenase-deficient newborns. Pediatrics 2001;108:25-30.

12. Martinez JC, Garcia HO, Otheguy LE, Drummond GS, Kappas A. Control of severe hyperbilirubinemia in full-term newborns with the inhibitor of bilirubin production Sn-mesoporphyrin. Pediatrics 1999;103:1-5.

13. Valaes T, Petmezaki S, Henschke C, Drummond GS, Kappas A. Control of jaundice in preterm newborns by an inhibitor of bilirubin production: studies with tin-mesoporphyrin. Pediatrics 1994;93:1-11.

14. Hintz SR, Vreman HJ, Stevenson DK. Mortality of metalloporphyrin-treated neonatal rats after light exposure. Dev Pharmacol Ther 1990;14:187-92.

15. Hajdena-Dawson M, Zhang W, Contag PR, et al. Effects of metalloporphyrins on heme oxygenase- 1 transcription: correlative cell culture assays guide in vivo imaging. Mol Imaging 2003;2:138-49.

16. Zhang W, Contag PR, Hardy J, et al. Selection of potential therapeutics based on in vivo spatiotemporal transcription patterns of heme oxygenase-1. J Mol Med (Berl) 2002;80:655-64.

17. Qato MK, Maines MD. Prevention of neonatal hyperbilirubinaemia in non-human primates by Zn-protoporphyrin. Biochem J 1985;226:51-7.

18. Hamori CJ, Vreman HJ, Rodgers PA, Stevenson DK. Zinc protoporphyrin inhibits CO production in rats. J Pediatr Gastroenterol Nutr 1989;8:110-5.

19. Appleton SD, Chretien ML, McLaughlin BE, et al. Selective inhibition of heme oxygenase, without inhibition of nitric oxide synthase or soluble guanylyl cyclase, by metalloporphyrins at low concentrations. Drug Metab Dispos 1999;27:1214-9.

20. Vreman HJ, Hintz SR, Kim CB, Castillo RO, Stevenson DK. Effects of oral administration of tin and zinc protoporphyrin on neonatal and adult rat tissue heme oxygenase activity. J Pediatr Gastroenterol Nutr 1988;7:902-6.
21. Wong RJ, Schulz S, Espadas C, Vreman HJ, Rajadas J, Stevenson DK. Effects of light on metalloporphyrin-treated newborn mice. Acta Paediatr 2014;103:474-9.

22. DeSandre GH, Wong RJ, Morioka I, Contag CH, Stevenson DK. The effectiveness of oral tin mesoporphyrin prophylaxis in reducing bilirubin production after an oral heme load in a transgenic mouse model. Biol Neonate 2006;89:139-46.

23. Morris BH, Oh W, Tyson JE, et al.; NICHD Neonatal Research Network. Aggressive vs. conservative phototherapy for infants with extremely low birth weight. N Engl J Med 2008;359:1885-96.

24. Tatli MM, Minnet C, Kocyigit A, Karadag A. Phototherapy increases DNA damage in lymphocytes of hyperbilirubinemic neonates. Mutat Res 2008;654:93-5.

25. Patra K, Storfer-Isser A, Siner B, Moore J, Hack M. Adverse events associated with neonatal exchange transfusion in the 1990s. J Pediatr 2004; $144: 626-31$

26. Schulz S, Wong RJ, Kalish FS, et al. Effect of light exposure on metalloporphyrin-treated newborn mice. Pediatr Res 2012;72:161-8.

27. Anderson KE, Simionatto CS, Drummond GS, Kappas A. Disposition of tin-protoporphyrin and suppression of hyperbilirubinemia in humans. Clin Pharmacol Ther 1986;39:510-20.

28. Galbraith RA, Kappas A. Pharmacokinetics of tin-mesoporphyrin in man and the effects of tin-chelated porphyrins on hyperexcretion of heme pathway precursors in patients with acute inducible porphyria. Hepatology 1989;9:882-8.

29. Goldberg M, Gomez-Orellana I. Challenges for the oral delivery of macromolecules. Nat Rev Drug Discov 2003;2:289-95.

30. Rodgers PA, Seidman DS, Wei PL, Dennery PA, Stevenson DK. Duration of action and tissue distribution of zinc protoporphyrin in neonatal rats. Pediatr Res 1996;39:1041-9.

31. Hintz SR, Kwong LK, Vreman HJ, Stevenson DK. Recovery of exogenous heme as carbon monoxide and biliary heme in adult rats after tin protoporphyrin treatment. J Pediatr Gastroenterol Nutr 1987;6:302-6.

32. Vreman HJ, Rodgers PA, Gale R, Stevenson DK. Carbon monoxide excretion as an index of bilirubin production in rhesus monkeys. J Med Primatol 1989;18:449-60.

33. He CX, Campbell CM, Zhao H, et al. Effects of zinc deuteroporphyrin bis glycol on newborn mice after heme loading. Pediatr Res 2011;70:467-72.

34. Adkins B, Leclerc C, Marshall-Clarke S. Neonatal adaptive immunity comes of age. Nat Rev Immunol 2004;4:553-64.

35. Vreman HJ, Rodgers PA, Stevenson DK. Zinc protoporphyrin administration for suppression of increased bilirubin production by iatrogenic hemolysis in rhesus neonates. J Pediatr 1990;117(2 Pt 1):292-7.

36. Morioka I, Wong RJ, Abate A, Vreman HJ, Contag CH, Stevenson DK. Systemic effects of orally-administered zinc and tin (IV) metalloporphyrins on heme oxygenase expression in mice. Pediatr Res 2006;59:667-72.

37. Donn SM. Lucinactant: a novel synthetic surfactant for the treatment of respiratory distress syndrome. Expert Opin Investig Drugs 2005;14: 329-34.

38. Phillips NC, Stewart-Phillips J, Wang P. Tumor cell binding and induction of endothelial cell tumoricidal activity in vitro by muramyl dipeptide is enhanced by liposomal encapsulation. J Immunother Emphasis Tumor Immunol 1994;15:185-93.

39. Stevenson DK, Watson EM, Hintz SR, Kim CB, Vreman HJ. Tin protoporphyrin inhibits carbon monoxide production in suckling mice. Biol Neonate 1987;51:40-4.

40. Vreman HJ, Stevenson DK. Heme oxygenase activity as measured by carbon monoxide production. Anal Biochem 1988;168:31-8. 